\title{
The effects of storms and a transient sandy veneer on the interannual planform evolution of a low-relief coastal cliff and shore platform at Sargent Beach, Texas, USA
}

\author{
Rose V. Palermo ${ }^{1,2}$, Anastasia Piliouras ${ }^{1,3}$, Travis E. Swanson ${ }^{1,4}$, Andrew D. Ashton ${ }^{5}$, and David Mohrig ${ }^{1}$ \\ ${ }^{1}$ Department of Geological Sciences, Jackson School of Geosciences, \\ The University of Texas at Austin, Austin, Texas 78712, USA \\ ${ }^{2}$ Joint Program in Oceanography/Applied Ocean Science and Engineering, Massachusetts Institute of \\ Technology/Woods Hole Oceanographic Institution, Woods Hole, Massachusetts 02543, USA \\ ${ }^{3}$ Earth and Environmental Sciences Division, Los Alamos National Laboratory, \\ Los Alamos, New Mexico 87545, USA \\ ${ }^{4}$ Department of Geology and Geography, Georgia Southern University, \\ P.O. Box 8149, Statesboro, Georgia 30460, USA \\ ${ }^{5}$ Department of Geology and Geophysics, Woods Hole Oceanographic Institution, \\ Woods Hole, Massachusetts 02543, USA \\ Correspondence: Rose V. Palermo (rpalermo@mit.edu)
}

Received: 22 March 2021 - Discussion started: 14 April 2021

Revised: 16 July 2021 - Accepted: 4 August 2021 - Published: 8 September 2021

\begin{abstract}
Coastal cliff erosion is alongshore-variable and episodic, with retreat rates that depend upon sediment as either tools of abrasion or protective cover. However, the feedbacks between coastal cliff planform morphology, retreat rate, and sediment cover are poorly quantified. This study investigates Sargent Beach, Texas, USA, at the annual to interannual scale to explore (1) the relationship between temporal and spatial variability in cliff retreat rate, roughness, and sinuosity and (2) the response of retreat rate and roughness to changes in sand and shell hash cover of the underlying mud substrate as well as the impact of major storms using field measurements of sediment cover, erosion, and aerial images to measure shore platform morphology and retreat. A storm event in 2009 increased the planform roughness and sinuosity of the coastal cliff at Sargent Beach. Following the storm, aerial-image-derived shorelines with annual resolution show a decrease in average alongshore erosion rates from 12 to $4 \mathrm{~m} \mathrm{yr}^{-1}$, coincident with a decrease in shoreline roughness and sinuosity (smoothing). Like the previous storm, a storm event in 2017 increased the planform roughness and sinuosity of the cliff. Over shorter timescales, monthly retreat of the sea cliff occurred only when the platform was sparsely covered with sediment cover on the shore platform, indicating that the tools and cover effects can significantly affect short-term erosion rates. The timescale to return to a smooth shoreline following a storm or roughening event, given a steady-state erosion rate, is approximately 24 years, with the long-term rate suggesting a maximum of $\sim 107$ years until Sargent Beach breaches, compromising the Gulf Intracoastal Waterway (GIWW) under current conditions and assuming no future storms or intervention. The observed retreat rate varies, both spatially and temporally, with cliff face morphology, demonstrating the importance of multi-scale measurements and analysis for interpretation of coastal processes and patterns of cliff retreat.
\end{abstract}




\section{Introduction}

Coastal cohesive cliffs may recede at rates of meters per year or more (Sunamura, 2015) depending on the intensity of waves, sea level rise, and the tools and cover effects of sediment abrasion (Sunamura, 1992, 2015; Limber and Murray, 2011; Young et al., 2014). Soft-sediment cliff erosion is variable and episodic in the alongshore direction (Sunamura, 2015), and internal sediment dynamics play an important role in the alongshore cliff morphology (Limber and Murray, 2011). However, the feedbacks between storms, sediment cover, and planform morphology of coastal cliffs remain poorly quantified (Limber and Murray, 2011; Limber et al., 2014; Sunamura, 2015). In the coming years, these coastal erosion processes along with climate-change-driven increases in hazards pose an increasing threat to coastal communities and infrastructure (Oppenheimer et al., 2015).

Sargent Beach, Texas, USA (Fig. 1), is a consolidated Holocene mud beach composed of floodplain sediments that outcrop as a low-relief sea cliff and Type-A (gently sloping) shore platform (Sunamura, 1992), ephemerally covered by sand and shell hash. Sargent Beach is found in a $17 \mathrm{~km}$ stretch of coast eroding at an average of $15 \mathrm{~m} \mathrm{yr}^{-1}$ over the last 3 decades, which makes it one of the fastest eroding shorelines globally (Luijendijk et al., 2018). This small and dynamic system can be examined as a model for erosion of larger coastal cliff systems, allowing us to understand and explore the feedbacks between planform morphology and the evolution of cliffs over timescales of months to years. Similar cohesive coastal cliffs exist globally, including in the Caribbean coast of Colombia (Paniagua-Arroyave et al., 2018), Lake Michigan, USA (Brown et al., 2005), and Walton-on-the-Naze, Essex, UK (Hutchinson, 1973).

We study this landscape at length scales of tens of meters and timescales of months to years to describe and understand the mechanisms of erosion that drive the high retreat rates at Sargent Beach. Monthly measurements allow us to evaluate the relationship between sediment cover and cliff face retreat rate and morphology. We use the cliff face morphology and retreat rates to evaluate the temporal and spatial relationships between roughness and sinuosity with storm events, as well as sediment cover. Shoreline change at Sargent has been historically analyzed using measurements spaced $50 \mathrm{~m}$ or more apart and averaged over decades (Sealy and Ahr, 1975; Stauble et al., 1991; Paine et al., 2011, 2014). These studies have shown over kilometers how erosion at Sargent beach is linked to a scarcity of sediment (Sealy and Ahr, 1975; Stauble et al., 1991), that plucking large blocks of mudstone is a main mechanism of erosion (Stauble et al., 1991), and how the rates of erosion at Sargent Beach have changed over long and short timescales compared to the whole Texas Gulf Coast (Paine et al., 2011, 2014). Our observations add definition to the resolution of study at this site by capturing change at the scale of the embayments in the cliff face and focusing on how the cliff face changes in response to tropical storms.
Investigating the retreat of the low-relief sea cliffs at Sargent is important for both the potential insights into larger coastal cliff systems it provides and for the local community, as it is the barrier between the Gulf of Mexico and the Gulf Intracoastal Waterway (GIWW). Because of its thin and narrowing nature, its sediment-starved character, a consistently high erosion rate, and the recurrence of hurricanes and tropical storms, Sargent Beach is at risk of breaching in the foreseeable future. This breaching would have major economic and environmental repercussions.

\section{Background}

\subsection{Coastal erosion processes and sea cliff evolution}

Substrate erosion in this low-relief, muddy coastal cliff environment is dominated by abrasion from water-entrained siliciclastic sand and shell fragments, as well as repeated wetting and drying of the foreshore substratum that causes polygonal fracturing, promoting quarrying of small mud blocks that in turn rapidly disaggregate into their constituent grains (Fig. 2a) (Anderson, 1986; Trenhaile, 1987; Hancock et al., 1998; Stephenson and Kirk, 2000; Stock et al., 2005). Abrasion of mud by shell hash and sediment occurs through four distinct styles of focused erosion. First, the focused impact of grains on the sea cliff base and energy dissipation from wave impact lead to undercutting at the toe of the cliff and subsequent gravity-induced failure of the overhanging cliff face (Brooks et al., 2012; Collins and Sitar, 2007; Kline et al., 2014; Quinn et al., 2010; Adams et al., 2005). Cliff retreat by such failures maintains a vertical cliff face through time (Gardner, 1983) (Fig. 2b). Second, the swash and backwash motion of water-entrained grains cuts grooves or runnels into the platform that are oriented roughly perpendicular to the shoreline and parallel to the direction of swash and backwash (Fig. 2c). These runnels develop because of the feedback between topography and erosion rate brought about by a focusing of the concentration of abrading particles within the linear troughs (Allen, 1987; Fagherazzi and Mariotti, 2012; Flood, 1983; Carling et al., 2018). Third, outsized pebble clasts grind potholes into the mud substrate (Fig. 2d) (Pelletier et al., 2015). Finally, a substratum consisting of subhorizontal beds with different erodibilities leads to the production of discrete, seaward-facing steps that are centimeters to decimeters in relief (Fig. 2e). These steps, potholes, and runnels are cut into a landward-migrating and gently seawarddipping shore platform at Sargent Beach.

On rocky coasts (including those composed of consolidated mud), the amount of sediment covering the foreshore and shoreface plays a key role in determining both the magnitude and pattern of substratum erosion (Sunamura, 1976; Robinson, 1977; Walkden and Hall, 2005; Limber and Murray, 2011; Young et al., 2014). Loose, mobile sediment can either facilitate this erosion by acting as abrasional tools or inhibit erosion by mantling and protecting the vulnerable 
(a)

(b)
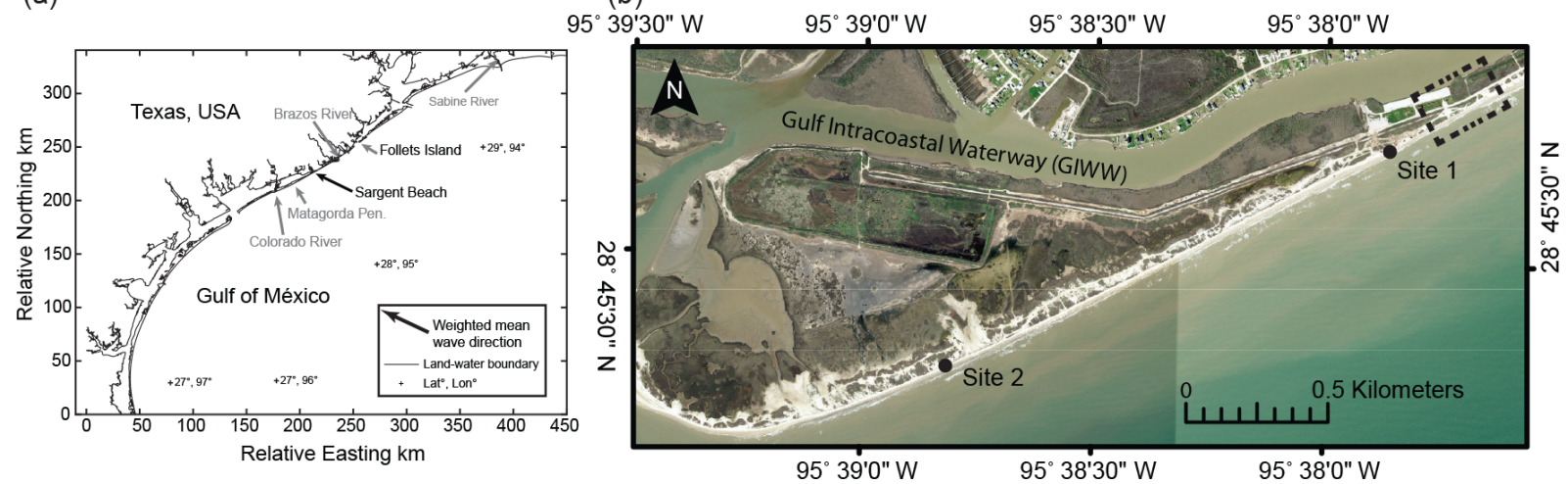

Figure 1. (a) Regional map of the Texas coast showing the location of Sargent Beach. (b) Aerial image of two survey sites at Sargent Beach, Texas. Dashed boxes denote the locations of Sites 1 and 2. Site 1: sea cliff. Site 2: shore platform. The dashed line represents the area where there is the least amount of land between the open ocean and the GIWW. Image source: NOAA. Hurricane Harvey: Emergency Response Imagery of the Surrounding Regions, 2017.

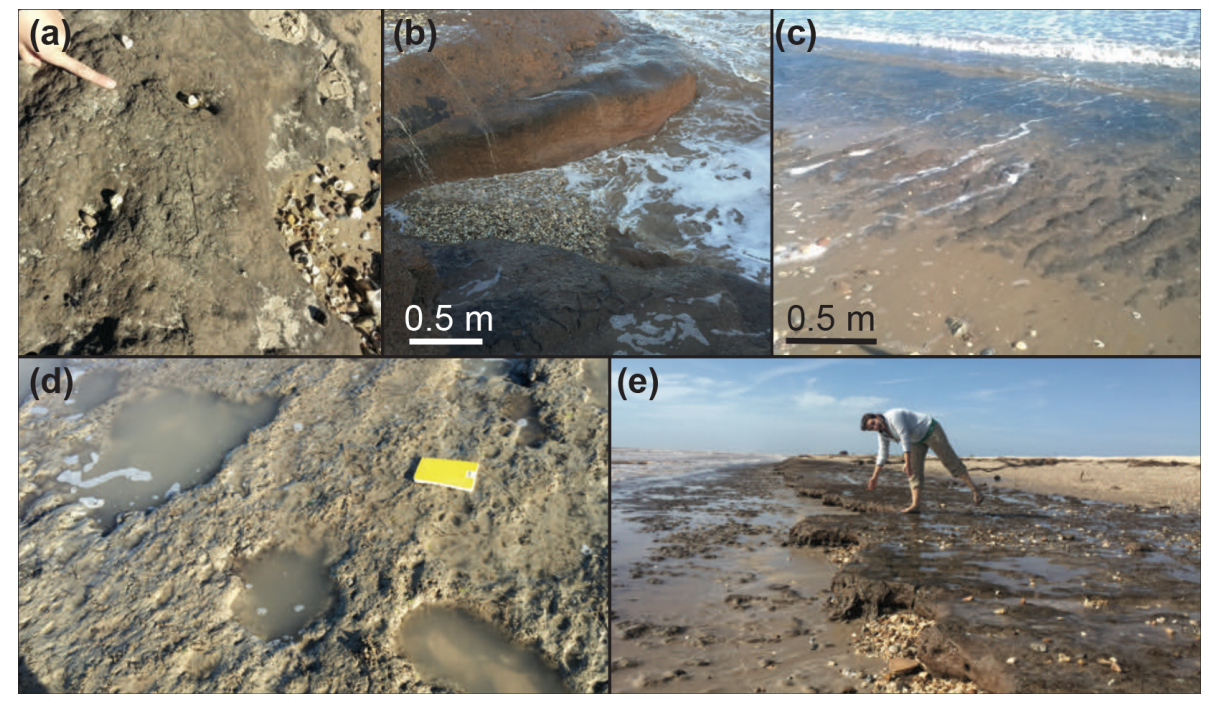

Figure 2. (a) Wetting and drying on the cliff. (b) Focused abrasion creating embayment at the cliff face. (c) Focused abrasion creating runnels on the shore platform. (d) Potholing and pothole coalescence on the shore platform. (e) Differential erosion and abrasion leading to production of a decimeter-scale step on the shore platform.

mud substrate (Sunamura, 1976; Robinson, 1977; Sklar and Dietrich, 2001, 2004; Walkden and Hall, 2005; Limber and Murray, 2011). The tools and cover effects have been widely studied in the context of bedrock river incision but largely overlooked for bedrock or mud substrate beach erosion under the influence of wave oscillation (Bramante et al., 2020).

Headland coasts tend to become less complex and straighter through time as headlands erode and bays fill in with eroded sediment (Trenhaile, 1987, 2002; Valvo et al., 2006; Limber et al., 2014). Rocky coastal cliffs have been shown to decrease in spatial variability of retreat rate through time, though this has not been quantitatively related to changes in shoreline roughness (Sunamura, 2015). Additionally, the soft cliff retreat rate has been directly linked to wave height (Brown et al., 2005). However, alongshore coupled models show that rocky coastlines can reach an equilibrium configuration wherein headlands and embayments remain stable over millennial timescales (Limber and Murray, 2011). Additionally, cliff erosion is episodic both temporally and spatially (Sunamura, 2015) and is at least partially controlled by sea level rise (Ashton et al., 2011).

\subsection{Sargent Beach setting}

Sargent Beach, Texas, USA, sits on a narrow, $150 \mathrm{~m}$ strip of barrier coast that separates the Gulf Intracoastal Waterway (GIWW) from the Gulf of Mexico (Fig. 1). Alongshore sediment transport at Sargent Beach is directed from the northeast to the southwest, and the mean tidal range is 
(a)
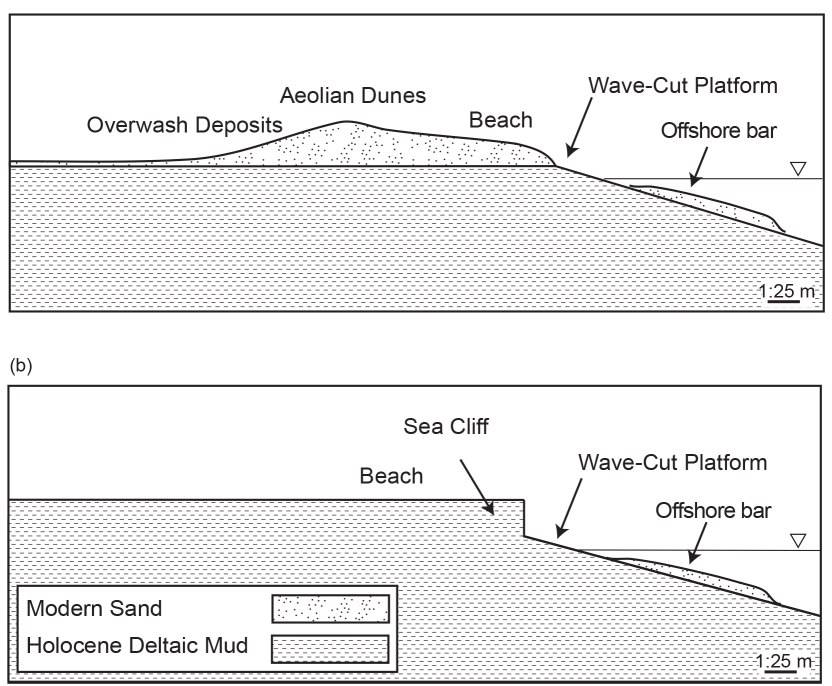

Figure 3. (a) Generalized cross section of the shore platform. (b) Generalized cross section of the shore platform and sea cliff system. $\sim 1: 25 \mathrm{~m}$ vertical exaggeration.

$20 \mathrm{~cm}$ (NOAA tide station 8772985). Ephemeral sand and shell hash are underlain by Holocene consolidated mud that commonly outcrops in the surf zone (Fig. 3a) (Paine et al., 2014). Inspection of cliff retreat maps of the Texas Gulf Coast reported in Paine et al. (2014) shows that the highest shoreline retreat rates occur at sections of the coast with exposed mud in the surf zone. Since 1856, the local shoreline has undergone $740 \mathrm{~m}$ of landward retreat at an approximately $5 \mathrm{~m} \mathrm{yr}^{-1}$ long-term retreat rate, putting the GIWW, a major inland barge transportation route, at high risk of breaching.

The Holocene mud substrate is composed of subhorizontal beds that are centimeters to decimeters in thickness, with varying densities of preserved plant roots. This muddy substrate consists of floodplain and marsh deposits from the Caney Creek overbank system, which was the larger Colorado River prior to its most recent avulsion and establishment of the modern river pathway (McGowen et al., 1975; McGowen and Macon, 1976). Compressive strengths for the Holocene mud substrate were estimated in the field using a Forestry Suppliers Pocket Penetrometer and range from $412 \mathrm{kPa}$ for dry mud to $206 \mathrm{kPa}$ for moist mud and very weak for submerged, fully saturated mud. The mudstone substrate is sculpted into a shore platform that often terminates at a low-relief sea cliff when the difference between local elevation of the Holocene mud substrate and sea level is sufficiently large (Fig. 3b) (Bradley, 1958; Stauble et al., 1991).

Sediment availability at Sargent Beach is insufficient to completely cover the foreshore at all times. This sedimentlimited environment allows sediment particles to act as tools of abrasion. The scarcity of loose sediment at Sargent Beach is linked to both the local mudstone lithology and its position $19 \mathrm{~km}$ down-shore from the trailing edge of the mod- ern Brazos River delta, which disrupts the littoral cell and captures the alongshore-transported sand as it grows seaward (Seelig and Sorensen, 1973; Sealy and Ahr, 1975; Morton et al., 2004). Meanwhile, constant wave action and little sediment supply result in a persistent erosion of Sargent Beach (Morton and Pieper, 1975; Morton, 1979).

"Nourishment" projects (placement of fill on the beach) have been implemented along Sargent Beach to mitigate extreme coastal erosion caused by large storms and an interruption of littoral drift by the protruding Brazos River delta that has been hypothesized to starve this section of coast of sand (Seelig and Sorensen, 1973; Sealy and Ahr, 1975; Morton et al., 2004).

In 1988, a combination of mud and sand dredged from the GIWW was emplaced on Sargent Beach in an effort to counteract cliff retreat. Most of this sediment was transported away from the nourishment site within 1 year (Morton and Paine, 1990). Another beach nourishment project was commissioned in 2013, which added $66723 \mathrm{~m}^{3}$ of sand onto Sargent Beach (Bush, 2015). Although average shoreline retreat rates are decreasing on the Texas Gulf Coast (Paine et al., 2014), despite these nourishment projects, at Sargent Beach shoreline retreat remains high.

\subsection{Storm history}

Over the past decade, Sargent Beach has experienced several intense storms, including Hurricane Ida in 2009, Tropical Storm Bill in 2015, and Hurricane Harvey in 2017. Hurricane Ida traveled north-northwest across the Gulf of Mexico towards the mouth of the Mississippi River in November 2009 as a tropical storm and later a Category 2 hurricane, before turning east and making landfall in Alabama (Avila and Cangialosi, 2010). Tropical Storm Bill made landfall near Matagorda Island on 16 June 2015 (Berg, 2015). Hurricane Harvey first hit the Texas Gulf Coast $\sim 150 \mathrm{~km}$ southwest of Sargent Beach on 26 August 2017 at Category 4 and returned to the gulf $\sim 65 \mathrm{~km}$ southwest of Sargent Beach on 28 August as a tropical storm passing over Matagorda Bay - a site less than $50 \mathrm{~km}$ from Sargent Beach (Blake and Zelinsky, 2017). These storms each produced large storm surge and waves that knocked out buoys and eroded Sargent Beach over the study period.

\subsection{Outline}

Here, we conducted a series of investigations of a rapidly evolving cohesive coast to study the dynamics across annual, monthly, and storm event scales to better understand cliff erosion process in the context of longer-term evolution. To evaluate the feedbacks between cliff face morphology and retreat rate, we use annual aerial images to digitize the cliff face and quantify the morphology and retreat. Monthly field surveys of sediment cover and cliff retreat give insights into the controls on erosion and morphology that sediment has in 


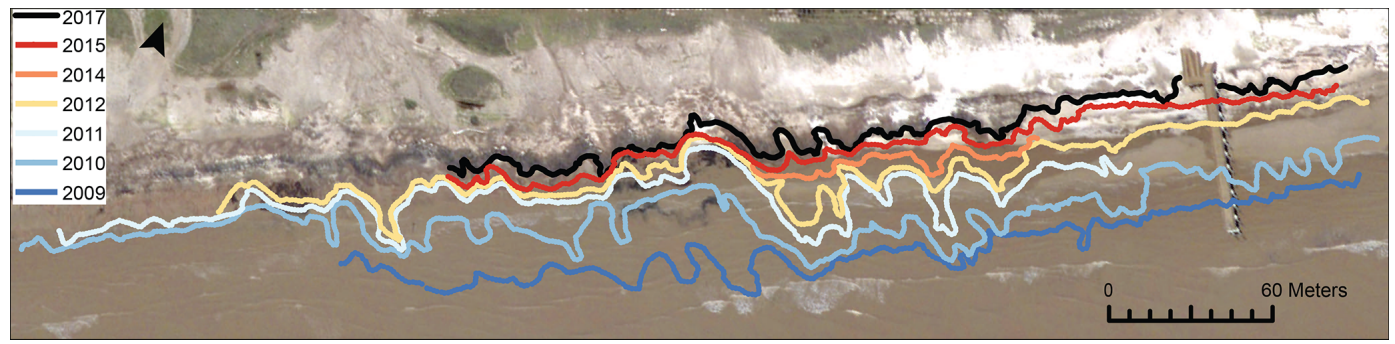

Figure 4. Plan view of shorelines delineated from subsequent approximately annual aerial images. Site 1 (see Fig. 1). Arrow points north. Image source: NOAA. Hurricane Harvey: Emergency Response Imagery of the Surrounding Regions, 2017.

this system. Finally, we use lidar of the cliff before and after Hurricane Harvey to study the effect a single major storm can have on cliff morphology.

\section{Methods}

Two field sites were chosen at Sargent Beach to compare erosion mechanisms, rates, and morphologies of shore platforms with sea cliffs (Fig. 1). Sargent Beach's sea cliff is located at Site 1 (Fig. 1). Site 2 is on the shore platform down-shore from Site 1 (Figs. 1 and 2).

\subsection{Remote sensing}

For the remote sensing analysis, we used approximately annual aerial images with $0.5 \mathrm{~m}$ resolution over the years 2009 , 2010, 2011, 2012, 2014, 2015, and 2017 (Fig. 4 and Table S1 in the Supplement). We manually traced the most landward position of the cliff face, which was easily identified visually by demarking either the contact between sediment armoring the shore platform below and the cliff, the contact between the cliff and the water, or the stark relief.

For the sea cliff, we calculated local retreat rates at $1 \mathrm{~m}$ alongshore intervals as the change in cliff position perpendicular to the reference line, which is a linear fitted trend line of mapped cliff faces (Fig. 4; $n=2725$ ). For each pair of aerial images, we compute the end point retreat rate by measuring the distance between the two cliff face positions and dividing by the time between the measurements (Genz et al., 2007; Fig. S1a in the Supplement). The detection limits based on pixel size $(0.5 \mathrm{~m})$ and georeferencing error (calculated for each image pair) both contribute to the uncertainty of calculated cliff retreat rates. This uncertainty is computed using the apparent displacement of single stationary structures in the images (i.e., the georeferencing error) and the pixel size.

In the same $1 \mathrm{~m}$ increments along the cliff faces, we calculated local roughness $(\mathrm{m})$ as the distance between the fitted cliff face trend line and the cliff face position (Fig. S1b). Similarly, pixel size represents the roughness uncertainty. We also calculate the sinuosity of the cliff face for each image, which is linearly correlated with roughness. The sinuosity is measured as the alongshore distance of the cliff face divided by the straight-line distance between the end points of the cliff face.

To evaluate three-dimensional changes in sea cliff morphology due to Hurricane Harvey, we analyze digital elevation models (DEMs) derived from airborne lidar collected by the United States Army Corps of Engineers in 2016 and by the Bureau of Economic Geology at the University of Texas in 2017, before and after Hurricane Harvey, respectively (OCM Partners, 2018; Bureau of Economic Geology Preliminary Post-Harvey Survey Map). We compare transects of both the sea cliff and the shore platform and define the mean elevation of each feature as the characteristic elevation of that morphology for Sargent Beach. We also compare transects of Site 1 from before and after Hurricane Harvey to observe topographic change in the sea cliff. Vertical uncertainty in these lidar datasets is $0.2 \mathrm{~m}$ (OCM Partners, 2018; Bureau of Economic Geology Preliminary Post-Harvey Survey Map).

\subsection{Field study}

To measure short-term changes and to ground-truth the remotely sensed data at both field sites, we conducted frequent elevation and local erosion surveys every 6 to 8 weeks throughout 2015 (Fig. 1). We measured 10 to 15 elevation survey transects perpendicular to the shoreline, with approximately $15 \mathrm{~m}$ spacing, beginning at the edge of the berm and extending approximately $30 \mathrm{~m}$ into the swash zone using a total station. Total station error is millimeter-scale, which is negligible relative to other sources of uncertainty. Each survey point was identified as mud substrate, mobile overlying sand, or a transition between the two. At Site 2, we used the total interpolated area of the study site and the areas of exposed mudstone substrate and sediment cover to calculate sediment cover as a percentage of the entire surface.

To determine local cliff face erosion rates, we placed erosion pins $(15.2 \mathrm{~cm}$ screws) flush against the cliff face, approximately 0.5 to $1 \mathrm{~m}$ up from the base of the cliff, on several locations perpendicular to, parallel to, and oblique to the best-fit shoreline trend to capture the spatial variability of erosion. To measure the distance the cliff face retreated lo- 

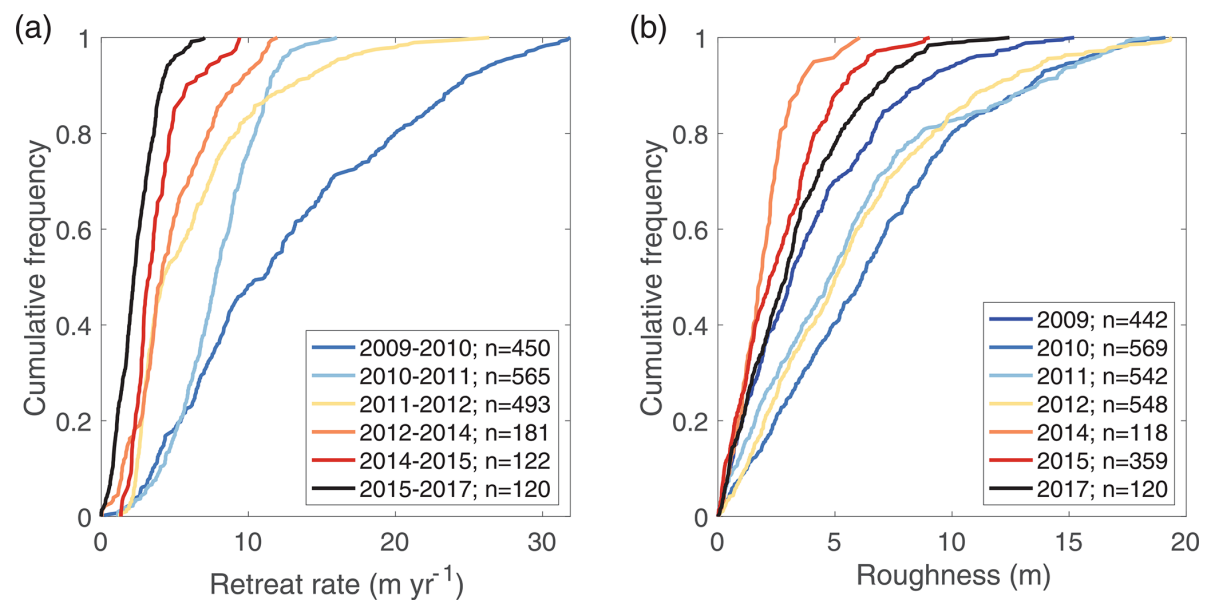

Figure 5. (a) Cumulative distribution function of retreat rate for each time interval. (b) Cumulative distribution function of cliff roughness for each time interval.

cally between surveys, we measured the length of the erosion pin exposed for each subsequent survey (Table S2).

To derive lateral retreat of the shore platform, we measured a vertical lowering of the platform using an Army Corps of Engineers survey mark located in the swash zone of Site 2 (See Fig. 1 for location of Site 2). In 1990, this survey mark was emplaced flush with the horizontal surface that is now the shore platform. Vertical lowering and platform slope measured in the field surveys were used to calculate lateral retreat.

\section{Results}

\subsection{Sea cliff: retreat rates, roughness, and sinuosity}

Local sea cliff erosion was spatially and temporally variable, with the promontories often experiencing higher erosion rates than the embayments during inter-storm periods and the embayments experiencing higher erosion rates than the promontories after a storm event (Figs. 4 and 5). Both the mean and the standard deviation of retreat rate decreased through time; the decrease was greater than the measurement uncertainty (Figs. 5 and 6a).

Overall, our measurements show that storm events increased the roughness and sinuosity of the shoreline, with high rates of erosion for years afterward. The retreat rate decreases steadily with time, starting with $12.4 \mathrm{~m} \mathrm{yr}^{-1}$ between 2009 and 2010 (following Hurricane Ida) to $2.4 \mathrm{~m} \mathrm{yr}^{-1}$ between 2015 and 2017 (following Hurricane Harvey) (Figs. 5a and 6a). Roughness and sinuosity both increase following Hurricane Ida and Hurricane Harvey (Fig. 6b-d). Mean roughness increased from 4 to $6.7 \mathrm{~m}$ after Hurricane Ida and from 2.6 to $3.3 \mathrm{~m}$ after Hurricane Harvey, which are $68 \%$ and $27 \%$ increases, respectively (Fig. 6b). Similarly, sinuosity increased from 1.4 to 1.7 following Hurricane Ida and 1.2 to 1.5 following Hurricane Harvey, which are $21 \%$ and $25 \%$ increases, respectively (Fig. 6c). In the years between these storms, roughness decreased with time from 6.7 to $1.9 \mathrm{~m}$ (Fig. 6b). Post-storm years contained fewer sea cliff protrusions, lower roughness values, and lower local erosion rates. Hurricane Harvey (2017) increased the roughness and sinuosity of the cliff face, but not enough to significantly increase the retreat rate.

\section{Modeling sea cliff steady-state retreat rate}

We perform a nonlinear least squares fit of the decay of retreat rate $(r)$ through time using an exponential model, $r(t)=a e^{-b t}+c$. Model fitting to the pre-Harvey retreat rate time series (Fig. 6a) yields fit values wherein parameter $a$ is $15.23 \mathrm{~m} \mathrm{yr}^{-1}, b$ is $0.2899 \mathrm{yr}^{-1}$, and $c$ is $1.399 \mathrm{~m} \mathrm{yr}^{-1}$ ( $c$ is the steady-state retreat value). This model fits our data with an $R$-squared value of 0.9966 . Using the fitted empirical model, we calculate a recovery timescale, $t_{\mathrm{r}}$, of 18 years (i.e., the time to return to steady-state conditions or attain $95 \%$ of the fitted steady-state retreat rate, $c$ ) by setting $r\left(t_{\mathrm{r}}\right)=0.95 c=$ $a e^{-b t_{\mathrm{r}}}+c$; therefore, $t_{\mathrm{r}}=(1 /-b) \ln (0.005 c / a)$. By dividing the $150 \mathrm{~m}$ width of the remaining barrier at Sargent Beach protecting the GIWW by the steady-state retreat value, $c$, we estimate a time to breach at Sargent Beach given background erosion conditions of 107 years. However, we measure an average retreat rate of $4.9 \mathrm{~m} \mathrm{yr}^{-1}$ over the study interval at the site using an ordinary least squares regression of shoreline position (Genz et al., 2007). Retreat at this rate would result in a breach of the GIWW in 28 years.

\subsection{Comparison of cliff retreat rates and sediment cover on the platform}

There is little to no cliff retreat when sediment cover is high (Fig. 7). During our survey, the high sediment cover measurements of $>90 \%$ resulted in burial of the erosion pins on the 
(a)

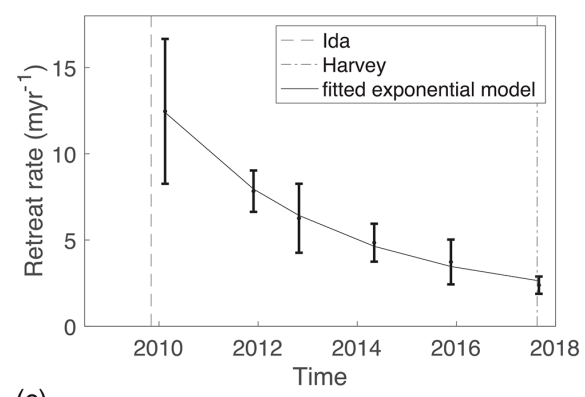

(c)

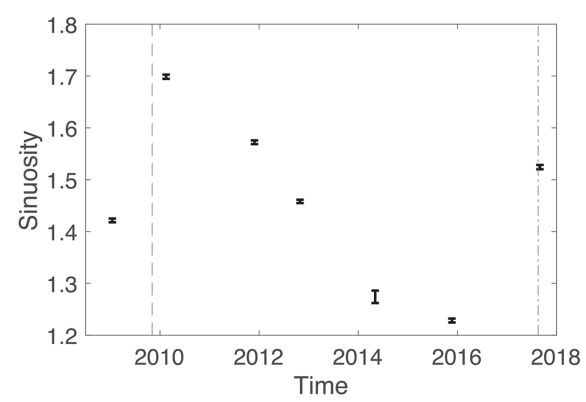

(b)

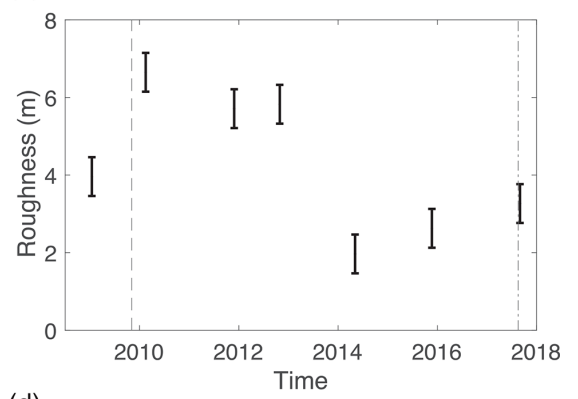

(d)

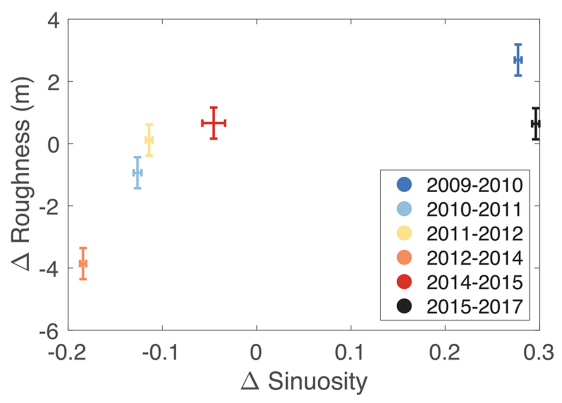

Figure 6. (a) Mean cliff retreat rate $\left(\mathrm{myr}^{-1}\right)$ through time. (b) Mean cliff roughness $(\mathrm{m})$ through time. (c) Cliff sinuosity through time. (d) Change in cliff sinuosity vs. change in mean cliff roughness. Error bars represent propagated error.

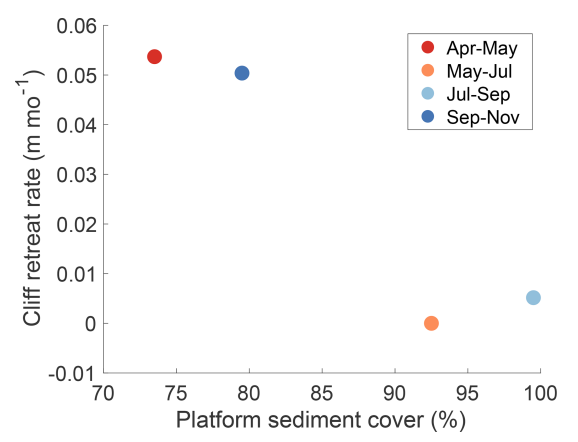

Figure 7. Platform sediment cover plotted against local cliff face retreat rate in meters per month $\left(\mathrm{mmonth}^{-1}\right)$ from monthly surveys conducted for the year 2015 .

cliff face and no measured erosion. Alternatively, all erosion pins were lost between April and May, which we interpret to represent erosion greater than or equal to the length of the pins $(15.2 \mathrm{~cm})$. For this time interval, the plotted value represents the minimum retreat that occurred in this period, which was $0.054 \mathrm{~m} \mathrm{month}^{-1}$. The erosion pins were buried via sand deposition that covered the cliff face between May and July, indicating no measurable erosion. The measured retreat rate from July to September was $0.005 \mathrm{mmonth}^{-1}$. The erosion pins were lost again between September and November, indicating a minimum retreat rate of $0.054 \mathrm{~m} \mathrm{month}^{-1}$.

\subsection{Effects of Hurricane Harvey on the sea cliff}

There is an approximately 0.5 to $1.5 \pm 0.2 \mathrm{~m}$ difference between the elevation of the top of the sea cliff and the elevation of the shore platform, as determined from 2016 lidar data (Fig. 9a). During Hurricane Harvey, the storm surge at Sargent Beach was recorded between 1.2 and $2.1 \mathrm{~m}$, which would have inundated the cliff (Blake and Zelinsky, 2017). After Hurricane Harvey, the sea cliff shows development of a second step in its topography with $0.8 \pm 0.2 \mathrm{~m}$ in relief (Fig. 9b). This change in topography is also seen in the $0.3 \mathrm{~m}$ contours of topography derived from the 2017 lidar (Fig. 9b). Two sets of tightened contours are present in the cross-shore direction in the 2017 data, representing the differential vertical erosion that developed the second step (Figs. 9b, 10).

We differenced the lidar-derived DEMs from 2017 and 2016 to find the areas of most topographic change at Site 1 (Fig. 9c). Evidence of overwash and wash-over deposits in the aerial imagery correspond to areas of accretion in the differenced lidar image. Maximum erosion occurred in the embayments and hollows of the cliff. Here, sediments easily accumulate and are used as tools of abrasion when entrained. Mud substrate relief was diminished after Harvey due to vertical lowering of the sea cliff itself. Additionally, the cliff face erosion in the alongshore direction, or lateral erosion, notably increases the width of embayments.

The mud substrate survey points allowed us to measure a shore-perpendicular shore platform slope of $1.15^{\circ}$. Between 8 February 2015 and 15 November 2015, we measured a vertical lowering of the platform of $15 \mathrm{~cm}$ and constant platform 
(a)

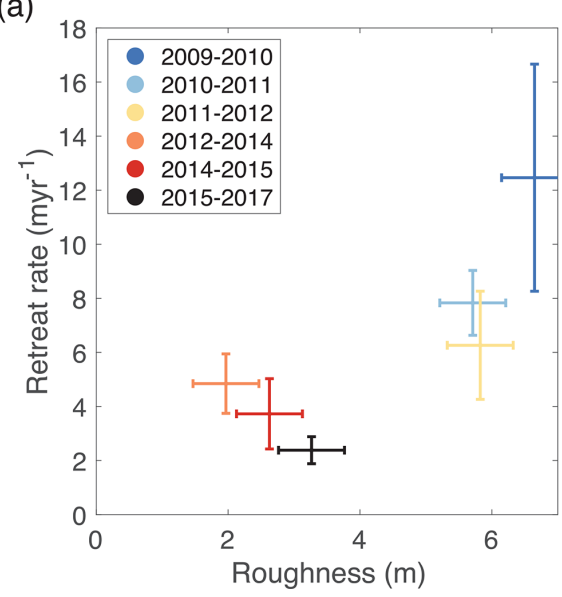

(b)

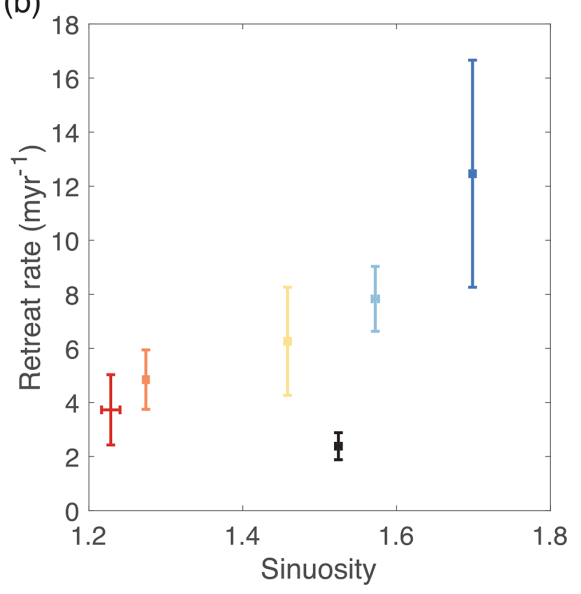

Figure 8. (a) Mean roughness of the second shoreline being differenced vs. mean cliff retreat rate. (b) Sinuosity of the second shoreline being differenced vs. mean cliff retreat rate.

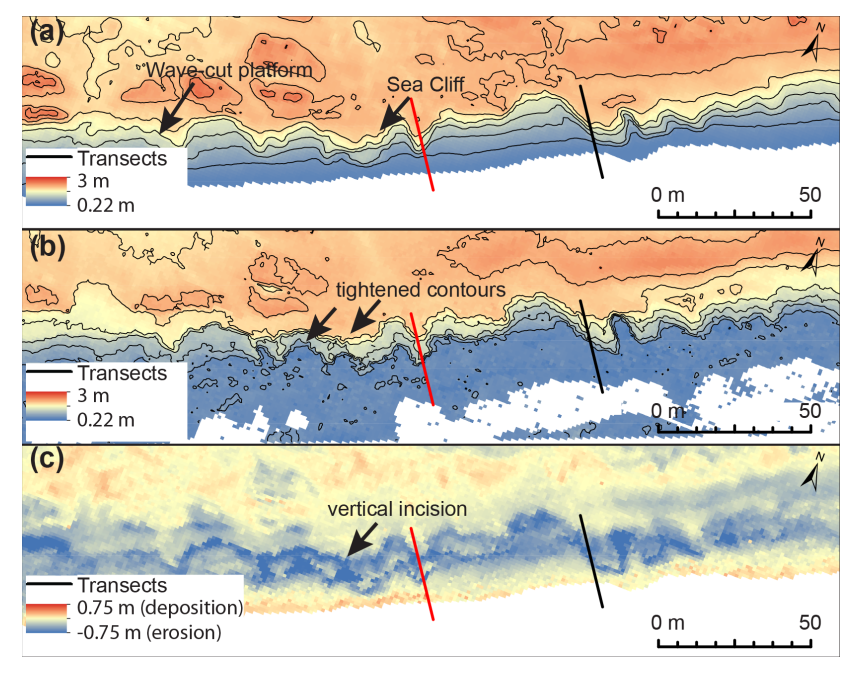

Figure 9. (a) 2016 lidar collected by the USACE at Site 1. Contour interval is $0.3 \mathrm{~m}$. Arrows point to locations on the beach where elevation and contour spacing indicate either the sea cliff or the shore platform. (b) 2017 lidar collected after Hurricane Harvey; ( ) Bureau of Economic Geology. Contour interval is $0.3 \mathrm{~m}$. (c) Difference between (a) and (b). The arrow points to the site of vertical incision. Transects are indicated by the black and red solid lines.

slope $\left(1.15^{\circ}\right)$ at the USACE survey mark. During the 2015 surveys, we measured a minimum of $0.23 \mathrm{~m}$ of lateral retreat of the sea cliff using erosion pins, while lateral retreat of the platform was estimated as $5 \mathrm{~m}$ using the USACE survey mark and platform slope. This is an order of magnitude difference between cliff retreat and platform retreat over the same survey period and less than $2 \mathrm{~km}$ in alongshore distance. (a)
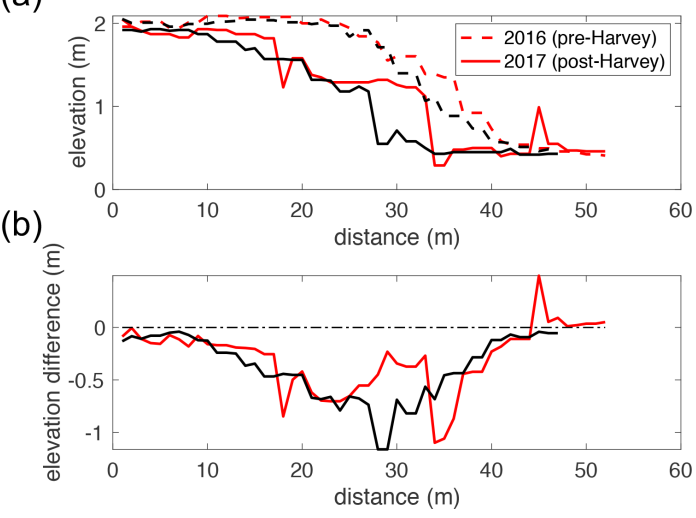

Figure 10. (a) Transects of beach before (dashed lines) and after (solid lines) Hurricane Harvey. (b) Difference between 2016 and 2017 transects. See Fig. 8 for locations of transects at Site 1.

\section{Discussion}

Changes in sediment cover are exogenic to cliff erosion at Sargent Beach and are instead driven by changes in sediment supply from storms, offshore, or up-coast. However, the amount of sediment in the system influences the morphology of the cliff face. Here we show that cliff retreat occurs when sediment cover is insufficient to bury the cliff, which occurs at approximately $90 \%$ sediment cover or less (Fig. 7). Additionally, our observations suggest that moderate sediment cover leads to erosion by sediment abrasion (Figs. 3 and 11). When there is not enough sediment cover to act as tools, waves preferentially erode the headlands, reducing the sinuosity and roughness of the cliff face, as occurred between the storm events during this study period (Figs. 11b and 6). However, when sediment cover is moderate and not high enough to bury the cliffs but sufficient to act as tools of 
(a)

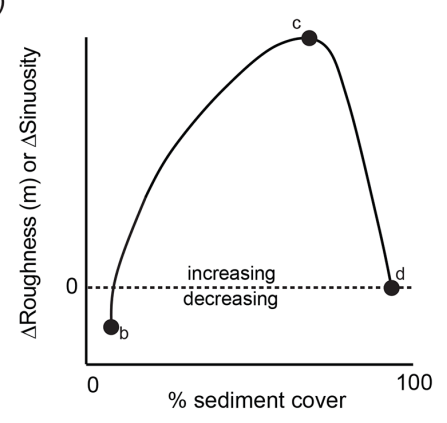

(b)

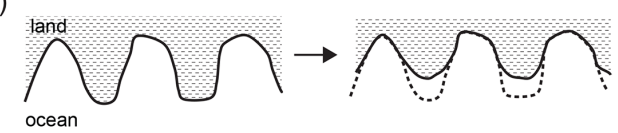

(c)

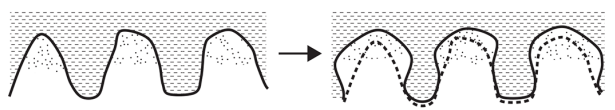

(d)

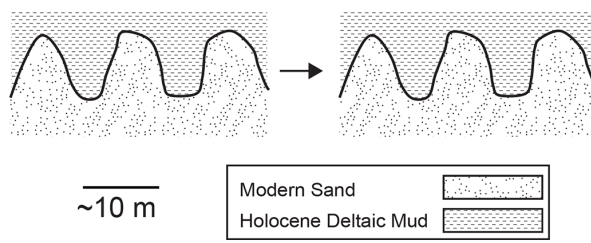

Figure 11. (a) Conceptual diagram of the relationship between change in cliff roughness or sinuosity with sediment cover percentage. Positive represents increasing roughness or sinuosity, and negative represents decreasing roughness or sinuosity. Plan view conceptual diagrams of cliff face erosion with (b) no sediment cover, (c) intermediate sediment cover, or (d) $100 \%$ sediment cover. The dashed line represents $t=1$ cliff face. Land is at the top and ocean is at the bottom for each panel.

abrasion, erosion is focused on the sides and back of the embayments, increasing the sinuosity and roughness of the cliff face (Figs. 2b, 6, and 11c). Following Hurricane Ida and Hurricane Harvey, when waves and storm surge were high, the embayments were deepened and widened (Fig. 4). This could be achieved through focused abrasion of the cliff face on the sides and in the embayments by shell hash (Fig. 3b). However, if sediment cover is sufficient to bury the cliff, no cliff erosion occurs and there is no change in cliff face morphology (Figs. 11d and 7). The cliff face was buried by sediment from Tropical Storm Bill and therefore became armored, resulting in no measured cliff erosion (Fig. 7). The persistence of the promontories suggests that the long-term effect of storms on the cliff morphology (deepening and widening promontories) is larger than that of the inter-storm periods when the promontories are preferentially eroded.

Because there is no feedback between erosion rate and sediment cover, as mudstone eroded from the cliff quickly disaggregates and leaves the system as wash load, storm occurrence controls erosion at Sargent via controls on both wave activity and sediment supply. If large quantities of mud were freed from erosion, a potential unexplored feedback could exist between the erosion of muddy cliffs and settled mud acting to dampen the wave energy, particularly for longperiod waves (Elgar and Raubenheimer, 2008). This feedback affects the morphology and erosion of coastal muddy cliffs and could be explored in future studies.

Hurricane Harvey was the most recent major storm to impact the area, making landfall on the Texas Gulf Coast in 2017. The sea cliff at Sargent Beach lost much of its form due to erosion during Hurricane Harvey. High storm surge during Harvey resulted in waves that overtopped the sea cliff and eroded vertically down rather than landward, as evidenced by the vertical step in the former sea cliff (Figs. 9, 10). Erosion due to Hurricane Harvey increased both the sinuosity and roughness of the cliff face. The observed sinuosity increase is attributed to erosion on the sides of the headland (Fig. 9), where sediment abrasion may be most efficient (Fig. 11c). Sediment cover is often highest in the embayments at Sargent Beach and lowest at the headlands. The spatial patterns and variability in sediment transport alongshore may play a critical role in determining where the peak erosive efficiency may be for sediment as tools of abrasion in larger cliff systems. This may have a larger control on sinuosity and roughness of cliff faces than previously expected, given the importance of sediment cover in this system.

In June 2015, Tropical Storm Bill made landfall on Sargent Beach, which was the only major storm during this study's field campaign. Instead of eroding and roughening the sea cliff, as Hurricane Ida and Hurricane Harvey did, Tropical Storm Bill induced sufficient foreshore sand deposition to cover and protect the cliff. Although storms can have a significant impact on coastal morphology, storm occurrence alone is not sufficient to infer net erosional processes. Storms can have highly variable effects on local coastal dynamics in this environment, depending upon sediment supply. Data collected throughout 2015 at Sargent Beach, Texas, USA, support the conceptual model that shore platform erosion is controlled by the balance between having (1) enough sand to abrade and erode the platform and (2) too much sand covering and protecting the platform from wave-induced erosion (Sunamura, 1976, 1982; Sklar and Dietrich, 2001, 2004; Walkden and Hall, 2005; Limber and Murray, 2011). Monthly variation in sand cover on the platform is correlated with monthly sea cliff retreat rates during the 2015 survey (Fig. 7), which is evidence for sand cover playing a critical role in cliff retreat at Sargent Beach.

When large storm events drive considerable roughening of the soft-sediment sea cliff, as shown for both Hurricane Ida and Hurricane Harvey, subsequent years of smaller storms 
and fair-weather waves then begin to smooth the roughened sea cliff and with initially high erosion rates. As roughness decreases through time, the cliff approaches what would be a stable morphology - a straight coastline. Sea cliff measurements from aerial imagery show a linear relationship between decreasing annual roughness and decreasing annual retreat rates between highly erosive events, such as Hurricane Ida (Fig. 8). If the shoreline were able to return to its steadystate conditions, cliff retreat and smoothing would likely occur at a relatively slow and steady rate compared to the poststorm condition. We can therefore infer that the optimal time to implement beach management strategies (i.e., beach nourishment) at Sargent Beach is the recovery timescale of about 18 years after a storm or shoreline-roughening event. However, given the prediction that tropical storms will increase in intensity in the coming years (Emanuel, 2005; Webster et al., 2005), the absence of a roughening storm event on the Texas Gulf Coast for an 18-year period of time is becoming increasingly less likely. Furthermore, we estimate the time to erode Sargent Beach and breach the GIWW to be between 28 years, assuming the average retreat rate continues, and 107 years, assuming the steady-state retreat rate and no future storms. Because erosion rates are high at Sargent Beach and there is little land left between the Gulf of Mexico and the GIWW, this conservative estimate of 107 years, and perhaps more realistic estimate of 28 years, represents a serious threat to the local coastal communities and the intracoastal waterway. The increasing storm intensity, lasting high retreat rates following storms, and the threat of sea level rise indicate that 107 years is an overestimation of the time to breach the GIWW at Sargent Beach.

The two sites studied at Sargent Beach demonstrate how relatively subtle differences in elevation control sea cliff occurrence. The sea cliff surface is $0.5 \mathrm{~m}$ to $1.5 \pm 0.2 \mathrm{~m}$ higher than the shore platform, which is commonly buried beneath a sandy beach berm. On stretches of beach with a lower-lying platform, wash-over fans often develop. On the sea cliff, sediment instead accumulates at its base, often acting as tools of erosion and filling in hollows and depressions in the cliff face intermittently before being reincorporated into the shoreface. Additionally, the shore platform underwent an order of magnitude faster retreat than the sea cliff over the 2015 survey period (Fig. 7). The long-term average of retreat at these locations is similar (Morton, 1977). However, these two sites are approximately $2 \mathrm{~km}$ apart, and both have undergone high rates of long-term retreat. Although the difference during this field study is large, $5 \mathrm{~m} \mathrm{yr}^{-1}$ is within the range of previous years' retreat rates of the sea cliff during the study time, with maximum local rates of retreat reaching $25 \mathrm{~m} \mathrm{yr}^{-1}$. Though elevation changes on this coastal landscape are small, small changes in elevation cause large changes in position for important plan view boundaries due to small coastal slopes. These small elevation changes have implications for the local resilience of the coastline through the varying erosion rates of the underlying mud substrate and the ability for over- wash fans to develop and aggrade narrow barriers like Sargent Beach and, in general, the coastal plain.

\section{Conclusions}

Storm occurrence and sediment cover jointly control the relationship between cliff roughness and cliff retreat on this cohesive cliff face. In this study, we measured the retreat rate, roughness, and sinuosity of the cliff face at Sargent Beach over about a decade of aerial imagery. We collected localized measures of cliff retreat, shore platform retreat, and sediment cover in repeat surveys throughout 2015. These data jointly allowed us to explore the relationship between sediment cover, storms, and planform morphology of the cliff face at Sargent Beach. Storms that greatly impact the morphology of Sargent Beach are not regular, resulting in long periods of slow retreat punctuated by highly erosional events. Between these events, the cliff retreat rate first increases with the initial increase in roughness, then decreases as cliff roughness decreases. Using an empirical model, we calculated an 18-year recovery timescale to the steady-state retreat rate after a roughening event. This may be interrupted by an additional roughening event, resetting the system before steady state is reached. Erosion by tropical storms can therefore cause longer-lasting high erosion rates by roughening the cliff. Changes in monthly cliff face retreat have similar trends as changes in sediment cover on the shore platform (higher erosion with lower cover and lower erosion with higher cover), suggesting that the tools and cover effect dominates cliff face retreat at this study site. Observations show that in this environment, sediment as tools of abrasion may be concentrated on the lateral edges of the headlands, increasing the sinuosity of the cliff face with high wave action. More work is needed to further quantify the effects of tools and cover in rocky and soft-rock coastal environments. The rapid erosion of this small, soft-sediment cliff may be used as a natural laboratory to understand the patterns of erosion on larger cliff systems.

Data availability. Data can be found in the Supplement and references in the text.

Supplement. The supplement related to this article is available online at: https://doi.org/10.5194/esurf-9-1111-2021-supplement.

Author contributions. RVP, DM, and AP designed the field data collection and remote sensing analysis. TES conducted the steadystate retreat rate modeling. All authors assisted with data analysis and paper revisions. 
Competing interests. The authors declare that they have no conflict of interest.

Disclaimer. Publisher's note: Copernicus Publications remains neutral with regard to jurisdictional claims in published maps and institutional affiliations.

Acknowledgements. Thank you to Joel Johnson, Sean Gulick, Styze van Heteren, Sarah Grace Lott, Christopher J. Hein, Juan Felipe Paniagua-Arroyave, Simon Mudd, and three anonymous reviewers for insightful comments. Thank you to Charlie Kerans, Clark Wilson, and Josh Lambert for assistance with field equipment. And finally thank you to the many field assistants and group members that helped collect and process the data: Alicia Sendrowski, Tim Goudge, Hima Hassenruck-Gudipadi, Ben Cardenas, Wayne Wagner, Kelsi Ustipak, Michael Toomey, and Dylan Rasch. This material is based upon work supported by Plan II at the University of Texas and the National Science Foundation Graduate Research Fellowship under grant no. 1745302.

Financial support. This research has been supported by the National Science Foundation (grant no. 1745302).

Review statement. This paper was edited by Simon Mudd and reviewed by Juan Felipe Paniagua-Arroyave and one anonymous referee.

\section{References}

Adams, P. N., Storlazzi, C. D., and Anderson, R. S.: Nearshore wave-induced cyclical flexing of sea cliffs, J. Geophys. Res.Earth, 110, 1-19, https://doi.org/10.1029/2004JF000217, 2005.

Allen, J. R. L.: Streamwise Erosional Structures in Muddy Sediments, Severn Estuary, Southwestern UK, Geogr. Ann. A, 69, 37-46, https://doi.org/10.1080/04353676.1987.11880195, 1987.

Anderson, R. S.: Erosion profiles due to particles entrained by wind: Application of an eolian sediment-transport model, Geol. Soc. Am. Bull., 97, 1270-1278, https://doi.org/10.1130/00167606(1986)97<1270:EPDTPE>2.0.CO;2, 1986.

Ashton, A. D., Walkden, M. J. A., and Dickson, M. E.: Equilibrium responses of cliffed coasts to changes in the rate of sea level rise, Mar. Geol., 284, 217-229, https://doi.org/10.1016/j.margeo.2011.01.007, 2011.

Avila, L. A. and Cangialosi, J.: Tropical Cyclone Report Hurricane Ida 4-10 November 2009, National Hurricane Center, available at: https://www.nhc.noaa.gov/data/tcr/AL112009_Ida. pdf (last access: 25 October 2018), 2010.

Berg, R.: Tropical cyclone report, tropical storm Bill, 16-18 June 2015, National Hurricane Center, 1-31, 2015.

Blake, E. S. and Zelinsky, D. A.: Tropical Cyclone Report: Hurricane Harvey, National Hurricane Center, 2017.

Bradley, W. C.: Submarine Abrasion and Wave-Cut Platforms, Bull. Geol. Soc. Am., 69, 967-974, https://doi.org/10.1130/00167606(1958)69[967:SAAWP]2.0.CO;2, 1958.
Bramante, J. F., Perron, J. T., Ashton, A. D., and Donnelly, J. P.: Experimental quantification of bedrock abrasion under oscillatory flow, Geology, 48, 541-545, https://doi.org/10.1130/G47089.1, 2020.

Brooks, S. M., Spencer, T., and Boreham, S.: Deriving mechanisms and thresholds for cliff retreat in soft-rock cliffs under changing climates: Rapidly retreating cliffs of the Suffolk coast, UK, Geomorphology, 153-154, 48-60, https://doi.org/10.1016/j.geomorph.2012.02.007, 2012.

Brown, E. A., Wu, C. H., Mickelson, D. M., and Edil, T. B.: Factors controlling rates of bluff recession at two sites on Lake Michigan, J. Great Lakes Res., 31, 306-321, https://doi.org/10.1016/S03801330(05)70262-8, 2005.

Bush, G. P.: Coastal Erosion Planning \& Response Act A Report to the 84th Texas Legislature, United States of America, Texas General Land Office, 1-25, 2015.

Carling, P., Williams, J., Leyland, J., and Esteves, L.: Stormwave development of shore-normal grooves (gutters) on a steep sandstone beach face, Estuar. Coast Shelf S., 207, 312-324, https://doi.org/10.1016/j.ecss.2018.04.024, 2018.

Collins, B. D. and Sitar, N.: Processes of coastal bluff erosion in weakly lithified sands, Pacifica, California, USA, Geomorphology, 97, 483-501, https://doi.org/10.1016/j.geomorph.2007.09.004, 2007.

Elgar, S. and Raubenheimer, B.: Wave dissipation by muddy seafloors, Geophys. Res. Lett., 35, L07611, https://doi.org/10.1029/2008GL033245, 2008.

Emanuel, K.: Increasing destructiveness of tropical cyclones over the past 30 years, Nature, 436, 686-688, https://doi.org/10.1038/nature03906, 2005.

Fagherazzi, S. and Mariotti, G.: Mudflat runnels: Evidence and importance of very shallow flows in intertidal morphodynamics, Geophys. Res. Lett., 39, 1-6, https://doi.org/10.1029/2012GL052542, 2012.

Flood, R. D.: Classification of sedimentary furrows and a model for furrow initiation and evolution, Geol. Soc. Am. Bull., 94, 630-639, https://doi.org/10.1130/00167606(1983)94<630:COSFAA>2.0.CO;2, 1983.

Gardner, T. W.: Experimental study of knickpoint and longitudinal profile evolution in cohesive, homogeneous material, Geol Soc. Am. Bull., 94, 664-672, https://doi.org/10.1130/00167606(1983)94<664:ESOKAL>2.0.CO;2, 1983.

Genz, A. S., Fletcher, C. H., Dunn, R. A., Frazer, L. N., and Rooney, J. J.: The predictive accuracy of shoreline change rate methods and alongshore beach variation on Maui, Hawaii, J. Coastal Res., 23, 87-105, https://doi.org/10.2112/05-0521.1, 2007.

Hancock, G. S., Anderson, R. S., and Whipple, K. X.: Beyond Power: Bedrock River Incision Process and Form, in: Rivers Over Rock: Fluvial Processes in Bedrock Channels, Geophysical Monograph-American Geophysical Union, 107, 35-60, https://doi.org/10.1029/gm107p0035, 1998, 1998.

Hutchinson, J. N.: The response of London Clay cliffs to differing rates of toe erosion, Geol. Appl. Idrogeol., 8, 221-239, https://doi.org/10.1016/0148-9062(75)91851-3, 1973.

Kline, S. W., Adams, P. N., and Limber, P. W.: The unsteady nature of sea cliff retreat due to mechanical abrasion, failure and comminution feedbacks, Geomorphology, 219, 53-67, https://doi.org/10.1016/j.geomorph.2014.03.037, 2014. 
Limber, P. W. and Murray, A. B.: Beach and sea-cliff dynamics as a driver of long-term rocky coastline evolution and stability, Geology, 39, 1147-1150, https://doi.org/10.1130/g32315.1, 2011.

Limber, P. W., Murray, A. B., Adams, P. N., and Goldstein, E. B.: Unraveling the dynamics that scale cross-shore headland relief on rocky coastlines: 1. Model development, J. Geophys. Res.Earth, 119, 854-873, https://doi.org/10.1002/2013jf002950, 2014.

Luijendijk, A., Hagenaars, G., Ranasinghe, R., Baart, F., Donchyts, G., and Aarninkhof, S.: The State of the World's Beaches, Sci. Rep., 8, https://doi.org/10.1038/s41598-018-24630-6, 2018.

McGowen, J. H. and Brewton, J. L.: Historical changes and related coastal processes, Gulf and mainland shorelines, Matagorda Bay area, Texas: Special Publication, Bureau of Economic Geology, The University of Texas, Austin, 1975.

McGowen, J. H. and Macon, J. W.: Environmental Geologic Atlas of the Texas Coastal Zone-Bay City-Freeport Area: Environmental Geology, Physical Properties, Environments and Biologic Assemblages, Current Land Use, Mineral and Energy Resources, Active Processes, Man-made Features and Water Systems, Rainfall, Stream Discharge, and Surface Salinity, Topography and Bathymetry, Bureau of Economic Geology, University of Texas, Austin, 1976.

Morton, R. A.: Historical shoreline changes and their causes, Gulf Coast Assoc. Geol. Soc. Trans., 27, 352-364, 1977.

Morton, R. A.: Temporal and spatial variations in shoreline changes and their implications, examples from the Texas gulf coast, J. Sediment. Petrol., 49, 11011111, https://doi.org/10.1306/212f78bf-2b24-11d78648000102c1865d, 1979.

Morton, R. A. and Pieper, M. J.: Shoreline changes in the vicinity of the Brazos River delta (San Luis pass to Brown Cedar Cut). An analysis of historical changes of the Texas Gulf shoreline, Texas Bur. of Econ. Geol. Circ. No. 75-4, https://doi.org/10.23867/gc7504d, 1975.

Morton, R. A. and Paine, J. G.: Coastal Land Loss in TexasAn Overview, Gulf Coast Assoc. Geol. Soc. Trans., 40, 625-634, https://doi.org/10.1306/20b231fb-170d-11d7$8645000102 \mathrm{c} 1865 \mathrm{~d}, 1990$.

Morton, R. A., Miller, T. L., and Moore, L. J.: National Assessment of Shoreline Change: Part 1, Historical Shoreline Changes and Associated Coastal Land Loss Along the US Gulf of Mexico, USGS Open-File Report, https://doi.org/10.3133/ofr20041043, 2004.

NOAA: Hurricane Harvey: Emergency Response Imagery of the Surrounding Regions, 2017, available at: https://storms.ngs. noaa.gov/storms/harvey/index.html\#14/29.8092/-95.2037, last access: 18 June 2020.

OCM Partners: 2016 USACE NCMP Topobathy Lidar DEM: Gulf Coast (AL, FL, MS, TX) from 2010-06-15 to 2010-08-15, NOAA National Centers for Environmental Information, https: //inport.nmfs.noaa.gov/inport/item/49427, last access: 8 October 2018 .

Oppenheimer, M., Campos, M., Warren, R., Birkmann, J., Luber, G., O’Neill, B., Takahashi, K., Brklacich, M., Semenov, S., Licker, R., and Hsiang, S.: Emergent risks and key vulnerabilities, in: Climate Change 2014 Impacts, Adaptation and Vulnerability: Part A: Global and Sectoral As- pects, 1039-1100, Cambridge University Press, Cambridge, https://doi.org/10.1017/CBO9781107415379.024, 2015.

Paine, J., Mathew, S., and Caudle, T.: Texas gulf shoreline change rates through 2007, Bureau of Economic Geology Report Prepared Under General Land Office Contract 10-041-000-3737 and National Oceanic and Atmospheric Administration Award NA09NOS4190165, 38 pp., 2011.

Paine, J. G., Caudle, T., and Andrews, J.: Shoreline Movement along the Texas Gulf Coast, 1930's to 2012, Bureau of Economic Geology Final Report prepared for General Land Office Under Contract 09-074-000, 52 pp., 2014.

Paniagua-Arroyave, J. F., Correa, I. D., Anfuso, G., and Adams, P. N.: Prediction of soft-cliff retreat in coastal areas with little information: The Minuto de Dios sector, Caribbean Coast of Colombia, J. Coastal Res., 81, 40-49, https://doi.org/10.2112/si81006.1, 2018.

Pelletier, J. D., Sweeney, K. E., Roering, J. J., and Finnegan, N. J.: Controls on the geometry of potholes in bedrock channels, Geophys. Res. Lett., 42, 797-803, https://doi.org/10.1002/2014GL062900, 2015.

Quinn, J. D., Rosser, N. J., Murphy, W., and Lawrence, J. A.: Identifying the behavioural characteristics of clay cliffs using intensive monitoring and geotechnical numerical modelling, Geomorphology, 120, 107-122, https://doi.org/10.1016/j.geomorph.2010.03.004, 2010.

Robinson, L. A.: Marine erosive processes at the cliff foot, Mar. Geol., 23, 257-271, https://doi.org/10.1016/00253227(77)90022-6, 1977.

Sealy, J. E. and Ahr, W. M.: Quantitative Analysis of Shoreline Change, Sargent, Texas, Texas A \& M University, TAMU-SG, 75-209, 1975.

Seelig, W. N. and Sorensen, R. M.: Investigation of shoreline changes at Sargent Beach, Texas TAMU-SG-73-212, Texas A\&M University Sea Grant, 153 pp., 1973.

Sklar, L. S. and Dietrich, W. E.: Sediment and rock strength controls on river incision into bedrock, Geology, 29, 1087-1090, https://doi.org/10.1130/00917613(2001)029<1087:SARSCO>2.0.CO;2, 2001.

Sklar, L. S. and Dietrich, W. E.: A mechanistic model for river incision into bedrock by saltating bed load, Water Resour. Res., 40, 6, https://doi.org/10.1029/2003wr002496, 2004.

Stauble, D. K., Burke, C.E, and Levin, D. R.: Rapid Erosion of A Cohesive Shoreline, Sargent Beach, Texas, in: Coastal Depositional Systems in the Gulf of Mexico: Quaternary Framework and Environmental Issues, SEPM Society for Sedimentary Geology, https://doi.org/10.5724/gcs.91.12.0249, 1991.

Stephenson, W. J. and Kirk, R. M.: Development of shore platforms on Kaikoura Peninsula, South Island, New Zealand II: The role of subaerial weathering, Geomorphology, 32, 43-56, https://doi.org/10.1016/S0169-555X(99)00062-8, 2000.

Stock, J. D., Montgomery, D. R., Collins, B. D., Dietrich, W. E., and Sklar, L.: Field measurements of incision rates following bedrock exposure: Implications for process controls on the long profiles of valleys cut by rivers and debris flows, Bull. Geol. Soc. Am., 117, 174-194, https://doi.org/10.1130/B25560.1, 2005.

Sunamura, T.: Feedback relationship in wave erosion of laboratory rocky coast, J. Geol., 84, 427-437, https://doi.org/10.1086/628209, 1976. 
Sunamura, T.: A wave tank experiment on the erosional mechanism at a cliff base, Earth Surf. Proc. Land, 7, 333-343, https://doi.org/10.1002/esp.3290070405, 1982.

Sunamura, T.: Geomorphology of Rocky Coasts, Wiley, Chichester, 1992.

Sunamura, T.: Rocky coast processes: with special reference to the recession of soft rock cliffs, P. Jpn. Acad. B-Phys., 91, 481-500, https://doi.org/10.2183/pjab.91.481, 2015.

Trenhaile, A. S.: The Geomorphology of Rock Coasts, Oxford University Press, Oxford, 1987.

Trenhaile, A. S.: Rock coasts, with particular emphasis on shore platforms, Geomorphology, 48, 7-22, https://doi.org/10.1016/S0169-555X(02)00173-3, 2002.

Valvo, L. M., Murray, A. B., and Ashton, A.: How does underlyng geology affect coastline change? An initial modeling investigation, J. Geophys. Res.-Earth, 111, 1-18, https://doi.org/10.1029/2005JF000340, 2006.
Walkden, M. J. A. and Hall, J. W.: A predictive Mesoscale model of the erosion and profile development of soft rock shores, Coast. Eng., 52, 535-563, https://doi.org/10.1016/j.coastaleng.2005.02.005, 2005.

Webster, P. J., Holland, G.., Curry, J. A., and Chang, H.-R.: Changes in Tropical Cyclone Number, Duration, and Intensity in a Warming Environment, Science, 309, 1844-1846, https://doi.org/10.1126/science.1116448, 2005.

Young, A. P., R. E. Flick, W. C. O'Reilly, D. B. Chadwick, W. C. Crampton, and J. J. Helly: Estimating cliff retreat in southern California considering sea level rise using a sand balance approach, Mar. Geol., 348, 15-26, https://doi.org/10.1016/j.margeo.2013.11.007, 2014. 